\title{
Morphologic analysis of developmental phases and gill ontogenesis in neotropical species Poecilia vivipara (Cyprinodontiformes: Poeciliidae) exposed to different salinities
}

\author{
Thiago L. Rocha'; Rodolfo Carvalho; Áureo T. Yamada² \& Simone M. T. Sabóia-Morais ${ }^{1,3}$ \\ ${ }^{1}$ Laboratório de Comportamento Celular, Departamento de Morfologia, ICB IV, Campus II, Universidade Federal de Goiás. \\ Caixa Postal 131, 74001-970 Goiânia, GO, Brazil. \\ ${ }^{2}$ Laboratório de Citoquímica e Imunocitoquímica, Departamento de Histologia e Embriologia, Instituto de Biologia, Universi- \\ dade Estadual de Campinas. Cidade Universitária Zeferino Vaz, Rua Monteiro Lobato 255, 13083-862 Campinas, SP, Brazil. \\ ${ }_{3}^{3}$ Corresponding author. E-mail: saboias@terra.com.br
}

\begin{abstract}
The present study evaluated and characterized the different phases of development and the cell types present in the gill epithelium of embryos, larvae, and fingerlings of guppy (Poecilia vivipara Bloch \& Schneider, 1801) specimens exposed to water with salinity ranging from $0 \%$ o to $20 \%$. The development of $P$. vivipara was classified into eight phases. The yolk was intensely eosinophilic, with glycidic and lipidic components between phases 1 to 7 . After the development of their branchial epithelium, the presence of pavement cells, mitochondria-rich cells, and mucous cells (MCs) was observed. The understanding of ontogenesis indicates the sequence of cellular origin. Only type IV MCs located in the gill rays was detected from phase 3 through phase 7. Other types of MCs were observed only when the fingerlings were exposed to salinity changes and showed to be lectin-reactive, thus indicating that $P$. vivipara modulates the cellular behavior when submitted to salinity changes. Exposure to variable saline concentrations did not interfere in the initial development of guppies. The presence of a yolk sac until the fingerling phase characterized this species as ovoviviparous.
\end{abstract}

KEY WORDS. Developmental biology; euryhalinity; guppy; mucous cells; teleosts.

Poecilia vivipara Bloch \& Schneider, 1801, known as guppies, also popularly called "guaru" and "barrigudinho" in Brazil, are small fish, approximately $4-5 \mathrm{~cm}$ long, belonging to a euryhalin cosmopolitan species originally from the American continent. The species is found in a variety of aquatic habitats, such as ponds, lakes, streams, rivers, and estuaries, and lives under different types of environmental conditions, ranging from freshwater (FW - 0 ppm) to brackish water (BW - 20 ppm) (SAB́́IA \& FERRI 1987).

Osmoregulatory mechanisms in the gills allow guppies to adapt to a variety of salinity levels, (SABÓIA \& FerRI 1987). Since the gills are in close contact with the surrounding medium, they represent one of the principal organs affected by the toxicity of chemical substances and variations in the water (ARAújo et al. 2001). Gills play other roles as well, including respiration, excretion of nitrogen products, and acid-base status (LAURENT et al. 1985, Machado \& Fanta 2003, Vigliano et al. 2006). The adaptive capacity of this species to tolerate different levels of salinity is directly related to mucous cell (MC) hyperplasia in the branchial epithelium, and also to the increased secretory activity of these cells, which promotes the formation of a superficial protective layer (SAbóia \& Ferri 1987, SabóiA-Morais et al. 1996).

Morphofunctional aspects are intimately related to ontogenetic processes and permit studying the different phases of embryonic development of fish following them up to the adult phase, and are highly important in acquiring global knowledge on the biology and systematics of fish species. More specifically, this allows the analysis of ontogenetic changes in morphology, growth, feeding, behavior, reproduction, and mortality; the acquired knowledge is applicable to taxonomy, aquaculture, selfecology, and population dynamics (NAKATANI et al. 2001).

Studying guppy development while taking into consideration the embryonic, larval, and fingerling phases, and consequently the diagnosis of the activation and differentiation of branchial epithelium cells, may lead to a better understanding of the morphophysiological mechanisms that account for the adaptation of this species to different saline concentrations. Researching the ontogenesis of the brachial epithelium of this species, one of the main targets of pollutants in aquatic environments, may also present the opportunity to conduct toxicological assessment of this biomonitor fish species throughout its development.

In the present contribution, we evaluate and characterize the most important phases that determine changes in origin, development, and differentiation of cell types that are present in the branchial epithelium of embryos, larvae, and fingerlings of specimens of $P$. vivipara exposed to estuarine and continental environments. 


\section{MATERIAL AND METHODS}

The protocol (126/2008) of this study was approved by the Medical Research Ethics Committee of Hospital das Clínicas, Universidade Federal de Goiás.

Adult specimens of $P$. vivipara were collected in streams located in the municipality of Goiânia (16 $35^{\prime} 37^{\prime \prime}$ S, $\left.49^{\circ} 16^{\prime} 50^{\prime \prime} \mathrm{W}\right)$ which form the continental water group. The animals were transported to the Laboratório de Comportamento Celular, in Instituto de Ciências Biológicas (ICB), at the Universidade Federal de Goiás (UFG), where they were kept in two acclimation tanks, each containing $49.632 \mathrm{~L}$ of filtered FW, for 24 hours.

After this period, 20 females at different stages of pregnancy were randomly removed from the adaptation tanks, had their fingerlings collected and were classified as follows: 1) recently fecundated; 2) intermediate stage of pregnancy in relation to (1) and (3); 3) end of pregnancy, characterized by very dilated and transparent ventral region allowing the visualization of the larvae. The females were individually kept in transparent plastic maternity-tanks containing $1.680 \mathrm{~L}$ of FW and aspects of their behavior (nutrition, swimming, color, and irritability) were monitored to assure their health and welfare and also to register the time of birth of the fingerlings. The same monitoring parameters were used to observe the behavior of the fingerlings.

After birth, the fingerlings were removed from FW, divided into five groups of five fingerlings each, and each group was exposed to a different salinity regimen $(0 \%$, $5 \%$, $10 \%$, $15 \%$, and $20 \%$ ) for two hours.

A second group of fish was collected in an estuarine environment, in the Botafogo river estuary, Itamaracá island, state of Pernambuco, Brazil ( $\left.7^{\circ} 45^{\prime} 51^{\prime \prime} \mathrm{S}, 34^{\circ} 52^{\prime} 45^{\prime \prime} \mathrm{W}\right)$ and kept at the Departamento de Anatomia, Instituto de Ciências Biológicas of the Universidade Federal de Pernambuco (UFPE), in Recife, state of Pernambuco. Sampling and maintenance procedures described above were also followed, except for the use of BW.

After birth, the fingerlings were removed from BW, divided into five groups of five fingerlings each, and each group was exposed to a different salinity regimen (20\%, 15\%o, 10\%o, $5 \%$, and $0 \%$ ) for two hours.

Each salinity level was achieved using commercial marine salt (Coralife, USA) for both FW and BW.

All the animals used in this experiment were fed ad libitum with commercial diet (Tetra, Germany) and the environmental conditions were kept as follows: $\mathrm{pH} 6.9$; temperature \pm $27^{\circ} \mathrm{C}$; with a 12 -hour light-dark natural cycle; and the level of ammonia dissolved in the water was 0-0.01 1/4/L.

In order to collect samples in different phases of development, 20 females of each group studied (estuarine and continental) were euthanized by decapitation (Brasil 2008) and their pregnancy stage was evaluated using a stereoscopic microscope (Metrimpex Hungary/PZO Labrimex). All the embryos and larvae collected in different stages of development, as well as the newly-born fingerlings (five specimens for each increasing salinity level and five for each decreasing salinity level) were fixed by immersion in Karnovsky solution for two hours (KaRNOvsKy 1965). Three specimens in each phase of development (from phase 1 to phase 7 ) of each salinity level regimen $\left(20 \%\right.$ o, $15 \%$ o, $10 \%$ o, $5 \%$, and $0 \%$ o) were post-fixed in $1 \% \mathrm{OsO}_{4}$ for two hours, dehydrated with increasing concentrations of acetone, critical point-dried with a Blazer CPD 030, mounted on stubs, coated with gold-palladium using a Blazer SCD 050, and examined in a JEOL 240 scanning.

The remaining specimens of embryos, larvae and fingerlings exposed to different salinity regimens were processed using the conventional histological technique, embedded in Paraplast (SEM, USA), and $4 \mu \mathrm{m}$-thick sections were mounted on glass slides, stained with Harris haematoxylin and eosin (HE) or submitted to the following histochemical reactions for the detection of glycoconjugates: Periodic Acid Schiff (PAS) (McManus 1948); PAS + Acetylation; PAS + Acetylation + Saponification (LILLIE \& Fullmer 1976); PAS + diastase (SPICER et al. 1967); PAS + Alcian Blue (AB) (Mowry 1956); AB pH 2.5 and AB pH 0.5 (Lev \& SPICER 1964); AB + Methylation and AB + Methylation + Saponification (SPICER \& LiLLIE 1959). The histochemical reaction using a panel of 12 biotinylated lectins (Tab. I) and streptoavidin-peroxidase (Dako Co, USA) were performed in the histological sections employing the technique described by PAFFARO JR et al. (2003). The analyses and photodocumentation were carried out with an OLYMPUS B071 photomicroscope.

\section{RESULTS}

\section{Guppy reproductive behavior}

Guppies reproduce by internal fertilization and the anal fin of the males is modified into a gonopodium to inseminate the females. Their entire embryonic development takes place within their mother's reproductive system. The females give birth to fingerlings by contraction of the ventral muscles and this mechanism generates circular movements that allow the young fish to rapidly reach the free-swimming stage.

In our study, females of the continental water group gave birth to an average of $12.2( \pm 0.836)$ fingerlings, regardless of salinity. We observed some premature fingerlings and some that were stillborn or cannibalized right after birth.

Cannibalism of fingerlings was also observed when the pregnant females were not separated from the other individuals of the group. In addition, a number of females had their ventral region lacerated as a result of cannibalism in the postdelivery period. We also registered some cases of lepidophagia affecting the lateral and caudal fins.

Adult $P$. vivipara individuals adjust to different levels of salinity. In the present experiment we observed their ability to survive in water with either increasing or decreasing salinity levels ranging from $0 \%$ to $20 \%$ right after birth. Both groups of newly-born fingerlings responded to changes in water salin- 
Table I. Biotinilated lectins and their respective inhibitory sugars.

\begin{tabular}{lll}
\hline Lectin common abbreviation & \multicolumn{1}{c}{ Lectin } & Inhibitory sugar \\
\hline LTA & Lotus tetragonolobus Agglutinin & L- $\alpha$-Fucose \\
UEA & Ulex Europaeus Agglutinin & L- $\alpha$-Fucose \\
PNA & Peanut Agglutinin & D-GalNac \\
WGA & Wheat Germ Agglutinin & D-GlcNAc \\
GSL-II & Griffonia simplicifolia Lectin II & D-Gal-Nac \\
RCA & Ricinus communis Agglutinin & D-Lactose \\
VVA & Vicia vilosa Agglutinin & D-Gal Nac \\
LCA & Lens culinaris Agglutinin & D-Man \\
PHA-E4 & Phaseolus vulgaris Erythroagglutinin & D-Gal-Nac \\
MAM & Maackia amurensis Lectin & Sialic acid \\
Con-A & Concanavalin A & D-Man
\end{tabular}

ity with alterations in their cell behavior, which seems to be directly related to the ability of this species to migrate from continental to coastal areas and vice-versa.

At the end of the experimental phase, pregnant females that had not delivered were dissected to verify the embryo and larval stages. We observed several distinct ontogenetic stages in $P$. vivipara.

\section{Mesoscopic aspects of the ontogeny}

In order to understand the ontogeny of $P$. vivipara, we classified the development of this species in eight different stages, taking into consideration the morphological characteristics observed under a stereoscopic microscope: phase 1) yolkrich egg with no clear demarcation lines along the embryo's body (Fig. 1); phase 2) embryo's body in curved shape involving yolk, with a demarcation in the area where the future eyeballs and vertebral column develop. Presence of pigments in the cranial region (Fig. 2); phase 3) embryo's body still curved with the vertebral column defined, formation of caudal fin, and, formation of the eyeballs and marked pigmentation on the cephalic region (Fig. 3); phase 4) individual presenting well defined body assuming long, cylindrical shape. Beginning of larval stage. It is possible to observe well formed eyes, presence of large yolk sac externally positioned in the ventral region and a large amount of pigment in the cranial region. Also, it is possible to visualize the central nervous system, with well defined and easily observed structures on the translucent dorsal region and the well developed mouth. The ventral and dorsal fins are visible (Fig. 4); phase 5) distinctively cylindrical shape, well developed eyes, yolk sac still external containing little yolk, pigmentation of cranial, lateral, and dorsal regions, well structured nervous system in dorsal region with intense pigmentation; phase 6) pre-parturition larva, cylindrical in shape, with open mouth, no visible yolk sac, and pigmentation all over the body (Figs 5 and 6); phase 7) fingerling or post-natal phase.
Newly-born $P$. vivipara are free-swimming fish, have well structured eyes and mouth, and are able to explore the environment; phase 8) post-fingerling. The young fish search for food since they begin exogenous feeding.

\section{Scanning electron microscopic analysis}

Upon analyzing the ontogeny of $P$. vivipara using a scanning electron microscope, we were able to identify the characteristics that can be used as established parameters to classify the development phases, particularly those related to the structural organization of the gills.

In phase 7, the fingerlings were able to explore the environment, since the structures related to their swimming capacity, acquisition of oxygen and nutrients had already developed. In this phase, the fingerlings presented open opercular and buccal cavities, well formed fins, and functionally active gills. In their gills, we observed arcs with organized rays, and the filaments already had their adaxial and abaxial surfaces defined, with the lamellae positioned perpendicular to the longer axis of the filament structure. All the branchial structures were covered with epithelium and the apical surface of the pavement cells had microridges (Figs 7 and 8).

\section{Microscopic characteristics of embryos and fingerlings}

Guppy embryos develop in the female reproductive system with cordonal organization. They are immersed in an amorphous substance, rich in acid carboxylated and/or sulphated glycoproteins reactive to $\mathrm{AB}$ pH 2.5 (Fig. 9).

The analyses of the embryonic development of $P$. vivipara using sections of phase 2-embryos stained with haematoxylin or $\mathrm{AB} \mathrm{pH} 2.5$ revealed the presence of the notochord and the neural tube with a lateral mass of cells, the somites. The latter is probably constituted by mesodermic cells in their initial stage of organization (Fig. 9). 

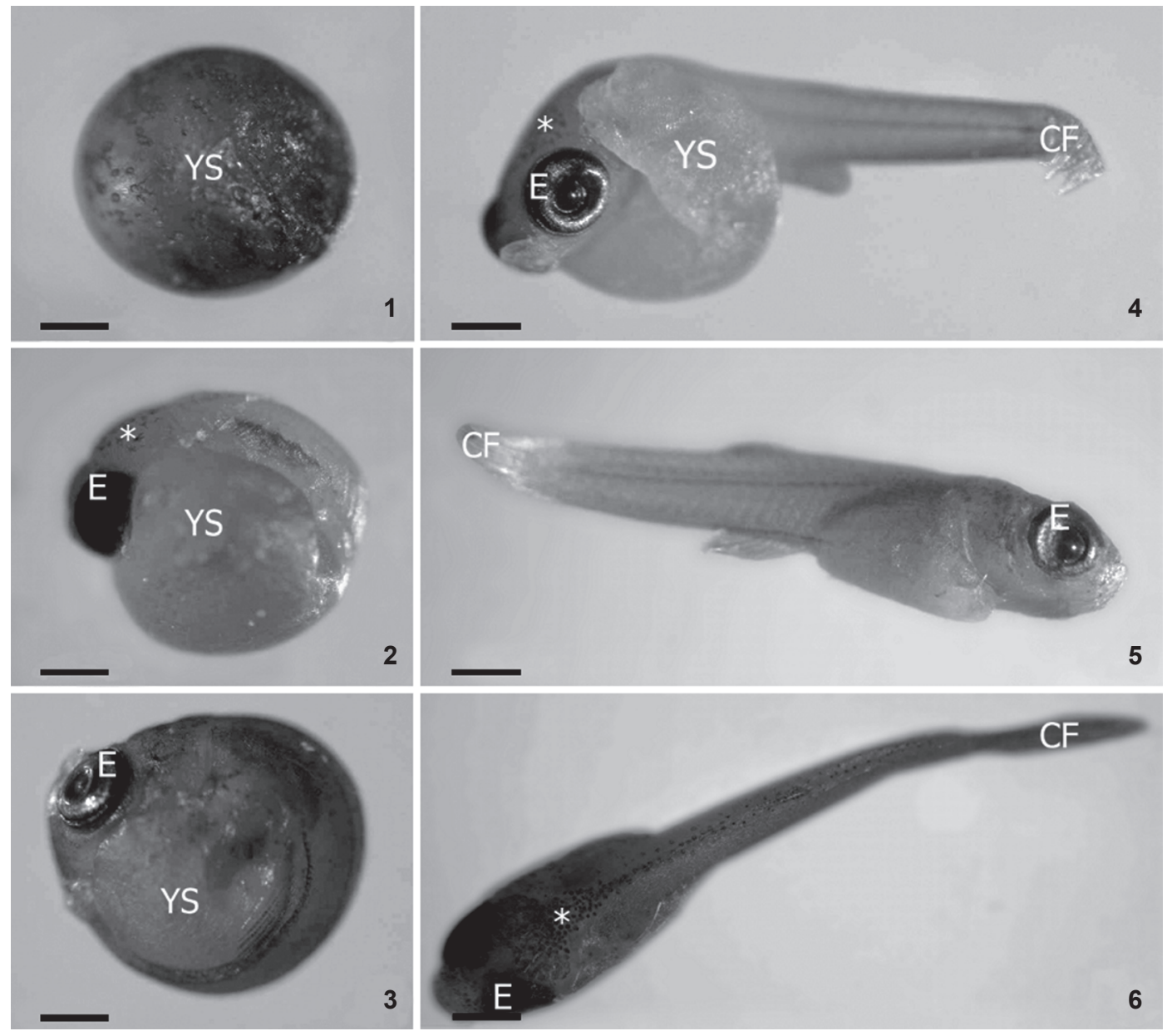

Figures 1-6. Stereomicroscopic observation of the phases of development of $P$. vivipara born to mothers exposed to freshwater: (1-4) Phase 1-4, lateral view; (5) Phase 6, lateral view; (6) Phase 6, dorsal view. Observe in the figures the yolk sac (YS), eyes (E), chromatophores $\left({ }^{*}\right)$, and caudal fin (CF). Scale bar: (1-3) $0.25 \mathrm{~mm},(4-6) 1 \mathrm{~mm}$.
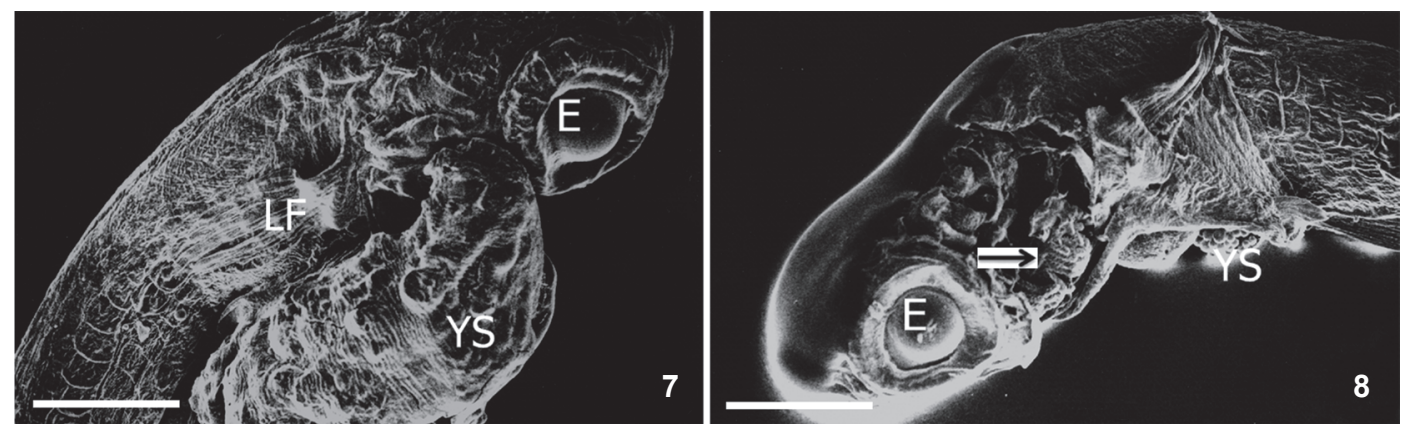

Figures 7-8. Conventional scanning electromicrograph analysis of $P$. vivipara phases of development: (7) Phase 4, lateral view. Observe in the cranial region the lateral position of the eye (E), yolk sac (YS), and lateral fin (LF). (8) Phase 6, dorsolateral view. Observe the eye $($ E) and gills $(\rightarrow)$. The gill cover was removed to visualize branchial arches. Scale bar: $60 \mathrm{~mm}$. 

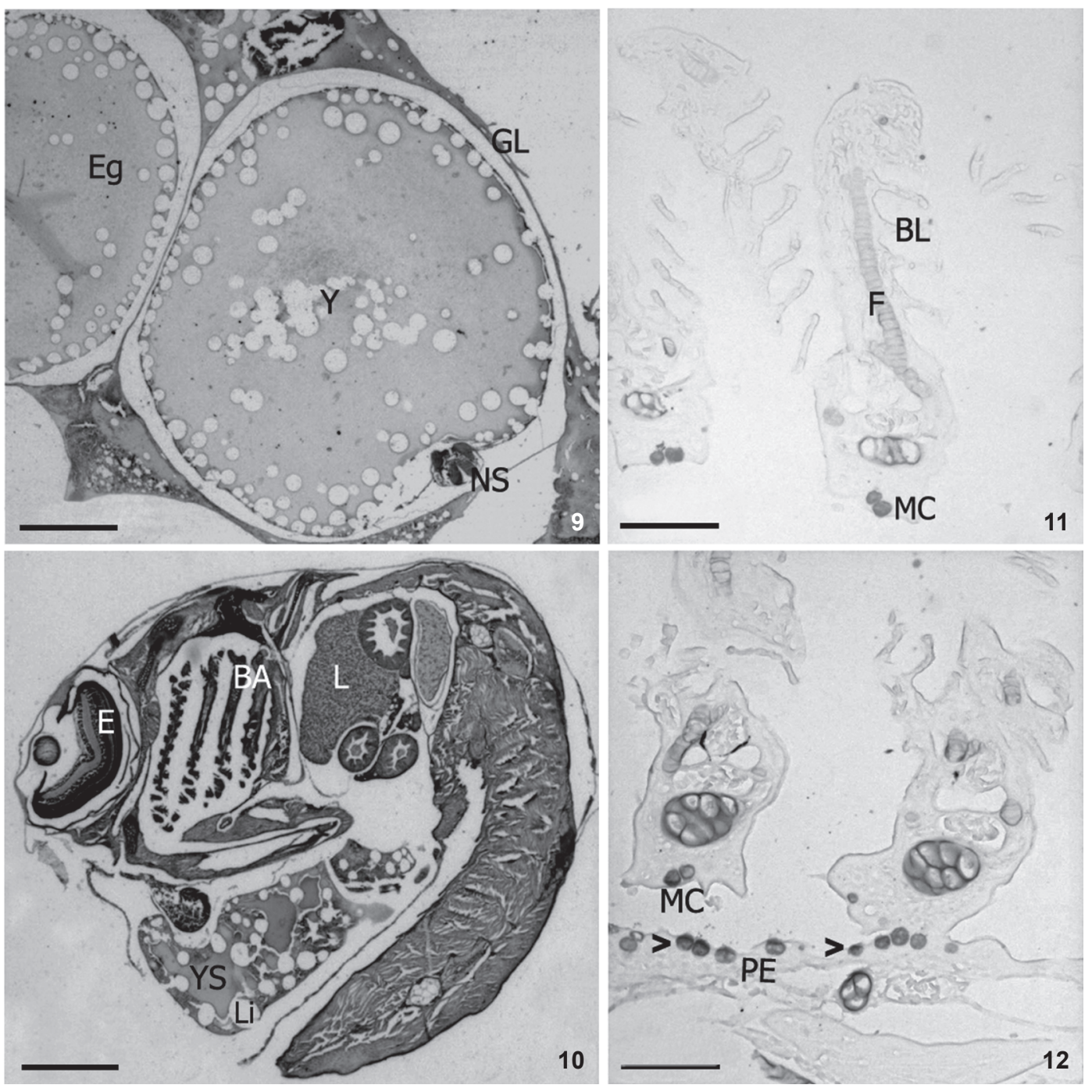

Figures 9-12. Histological and histochemical analysis of $P$. vivipara phases of development: (9) transversal sections of eggs and embryos in phase 1: observe the gelatinous layer (GL), yolk (Y), and developing nervous system (NS); (10) longitudinal section of phase 3: embryo containing yolk sac (YS), branchial arches (BA), liver (L), lipidic inclusions (Li), and structured eyes (E); (11) section of larva gills in phase 5: observe the filament with cartilaginous axis (F), branchial lamellas (BL), and mucous cells type IV (MC) Alcian Blue (AB) $\mathrm{pH} 2.5$ reactive; (12) section of gills in phase 5: observe the mucous cells type IV (MC) and the mucous cells $(>)$ of the pharinx epithelium (PE) Alcian Blue (AB) $\mathrm{pH} 2.5$ reactive. Methods: (9, 11-12) AB pH 2.5, (10) PAS+AB pH 2.5. Scale bar: (9) 300 mm, (10) $500 \mu \mathrm{m},(11-12) 50 \mu \mathrm{m}$.

In phase 2, we were able to observe eyeball formation and an intense vascularization around the yolk. This vasculogenesis process is precocious and is seen when the embryo forms a dense and well defined cell mass.

In phases 1 and 2, we detected in the embryo yolk a simple pavement epithelium leaning over a thin layer of extraembryonic mesenchyma, which is gradually irrigated by thin blood vessels.
From phase 2 on, angiogenesis is intensified and the vascularization around the yolk is enhanced. The blood vessels, morphologically similar to capillaries in the beginning, start thickening during phase 3 , and it is possible to distinguish venules and arterioles near the embryo. Most larvae present a ventrally positioned internalized yolk when they are ready to hatch.

In the initial phases of development, i.e., from phase 1 to phase 5 , guppies present an intensely eosinophilic yolk with 
high amounts of lipids, reactive amylase-sensitive PAS components as well as amylase-resistant components, which also have low intensity reaction to $\mathrm{AB} \mathrm{pH} 2.5$.

As the embryonic and larval development proceeds, glycogen and lipids are consumed and, consequently, there is a decrease in the amount of these substances. The yolk that remains in the fingerlings continues being PAS-positive and weakly amylase-resistant. It shows predominance of amylasesensitive components as well as lipid drops, indicating strong decrease in glycogen amount and persistence of neutral glycoconjugates in the yolk (Fig. 10).

In phase 2, the branchial arc sprouts appear; in the beginning of phase 3, they already display MCs type IV in the regions that will originate the branchial rays. In the regions that will originate the filaments, we detected pavement and mitochondria-rich cells. In phases 4 and 5, MCs AB pH 2.5reactive were easily observed at the base of the branchial rays and in the pharynx epithelium (Figs 11 and 12).

From phases 3 to 7 (post-delivery), there are outstanding organogenesis processes and structural alterations in the gills can be easily followed. Among them, are the gradual formation of the cartilaginous axis and the enhancement of the branchial lamellae, with intense vascularization. At the end of phase 7 , the columnar cells (characterized by having the vertical axis longer than the horizontal axis) that support the lamellar structure, the mitochondria-rich cells, and the pavement cells are easily observed and distinguished. From phases 3 to 7, MCs types I, II, and III were not found using either the classical histochemical techniques to detect glycoconjugates or the method for the detection of lectin-binding sites of glycoproteins.

The analyses of embryos born to mothers exposed to both BW and FW did not show any differences in their development or types of cell in any phases studied.

In phase 7 , guppy fingerlings exposed to both BW and to FW presented branchial structure with branchial arcs, filaments, and lamellae at the end of their formation process . In these structures we detected chloride cells, pavement cells, mucous cells, cartilaginous axis, blood vessels, and connective tissue cells. Nevertheless, the frequency and distribution of the cell subpopulations presented differences between the two groups under study (BW and FW).

\section{Effects of salinity on the development of respiratory structures}

In the branchial epithelium of fingerlings exposed to FW 0\%o and BW 20\%o we detected chloride cells and only MCs type IV in the branchial rays. However, an increase in the frequency of the latter was observed in the branchial rays and in the pharynx epithelium as the salinity increased from $0 \%$ to $20 \%$ in FW or decreased from 20\% to 0\% in BW. MCs type III were first observed in fingerlings exposed to FW $10 \%$ for two hours. First, MCs appear in branchial rays and, posteriorly, they are seen in the intermediary region of the filaments.
Lectin cytochemical analyses were performed with the aim of evaluating possible variations in the glycoconjugate composition of MCs in response to environmental salinity. In the embryonic and larval phases, the glycoconjugate content in guppy MCs was homogenous, with no outstanding alterations, even when the female was exposed to changes in salinity.

In fingerlings exposed to BW $20 \%$ for two hours, we detected a strong lectin-positive reaction in MCs type III to $\mathrm{PHA}_{-} \mathrm{E}_{4}$ and a weak reaction to RCA. In this treatment it was possible to observe an aggregate of mitochondria-rich cells in the surface of the epithelium. These cells had their surface strongly marked, which suggests a positive reaction with the glycocalix, or even an increase in the reactivity due to the elimination of the granule content in the MCs. The ostia of mitochondria-rich cells were also marked with PHA- $_{4}$ and RCA, which might imply the presence of the same glycoconjugates rich in Gal Nac and $\beta-G a l / \alpha-G a l G a l N A c$, respectively. MCs type IV also showed positive, but moderate, reaction to PNA.

No reactions to the selective markers were observed for the specimens exposed to FW $0 \%$, and the reactions to lectins WGA, LTA, and DBA were negative in all treatments.

\section{DISCUSSION}

The guppies were first classified as a viviparous species (Bloch \& SChNeider 1801), probably due to the fact that they have internal fertilization and embryo development, and also because the gonopodium was identified during the observations. Although this initial classification has not changed, our data show that guppies are not viviparous, but ovoviviparous. Even though their development takes place inside the mother's body, each embryo possesses its own yolk sac rich in glycoconjugates and lipids.

The embryos use the energy reserves contained in the yolk sac and, at birth, the fingerlings still have a remaining stock of nutrients in their body, next to the liver and intestines which allows them to survive for a period of time without needing to find food immediately. According to SATo et al. (2003), the opening of the oral cavity and total absorption of the yolk sac signal the need for exogenous nutrition.

The main components of the guppy yolk sac are glycidic and lipidic substances, and among them is glycogen, identified by the positive reaction to PAS + salivary amylase. Nonetheless, there is a group of amylase-resistant compounds that also present a low-intensity reaction to $\mathrm{PAS}$ and is $\mathrm{AB} \mathrm{pH} 2.5$ positive. Therefore, in addition to glycogen, the yolk sac contains neutral and acid carboxylated and/or sulphated glycoproteins, as well as lipid drops interwoven in the glycoprotein mass.

The presence of yolk in the post-natal period is comparable to the correspondent phase of development of species that present external fertilization, such as Leporinus piau (Fowler, 1941), Gadus morhua (Linnaeus, 1758), and Prochilodus lineatus (Valenciennes, 1847) (Borçato et al. 2004, FaLk-Petersen 2005, Ninhaus-Silveira et al. 2006, Gomes et al. 2007). In these species, 
the yolk remains are the reserves of energy used by the larvae in the first hours of life, until they are able to find their own nutrition source. In the guppies, the individuals keep the reserve of energy after birth, in phase 7 (fingerling), and this can be used as a nutrition source for a maximum of 24 hours after birth, i.e., when they become free swimmers and can explore the environment with no need to find nutrients immediately.

The nutritional independence provided by the yolk is of great importance both to the organogenesis and ontogenesis of guppy embryos. However, in order to develop, these animals need to intensify their cell metabolism by releasing catabolites and transferring small molecules and dissolved gases to the mother's body. The embryo receives oxygen and some fluids from the mother, which may indicate maternal-fetal interactions. Nevertheless, as already described by ARAújo et al. (2001), when certain components, such as methylmercury, are dissolved in the water where pregnant females live, no passage of these substances to the embryos can be observed. This might happen due to the weight of these molecules, aggregation to other molecules inside the mother's body, or because the embryos are involved by a gelatinous layer rich in acid carboxylated and/or sulphated glycoproteins. The latter would provide a protective layer around the embryos and work as a barrier against the diffusion of several molecules. Then, it is believed that the flow of molecules between the mother and the embryos and/or larvae is limited by molecule weight.

The development of the respiratory system is of vital importance for the survival of a guppy fingerling. Fish gills have certain functions that are essential to maintain the homeostasis of the organism, for instance: gas exchange and oxygen supply (respiration), osmoregulation, maintenance of a stable acid-base status, reception of stimuli, taste, secretion of catabolites and substances that protect against irritation caused by external agents (LAURENT et al. 1985, MACHADO \& FANTA 2003, VigLiano et al. 2006).

By increasing the functional activity of gills, several fish species achieve higher rates of gas exchange and get more energy, which allows the larvae to reach the free-swimming stage and search for food (FALK-Petersen 2005), similar to what we observed in phase 2 of guppy development, when the branchial arc sprouts appear.

We have detected that the development of the lamellae and the filament tips only takes place in phase 7 , making the branchial epithelium of fingerlings ready to perform its distinctive functions. With the advance in branchial development, the respiratory surface is enhanced, consequently guaranteeing more contact of this surface with the external media and providing the fingerlings with the necessary conditions to look for exogenous nutrition and escape from predators. These are physiological activities that occur in most teleost species (Moyle \& CECH JR 1996).

The stages of segmentation and organogenesis in fish are characterized by the initial formation of organs and systems. It is possible to observe the notochord, neural tube, somites, delimitation of the digestive system with the consequent growth and elongation of the axial structure. The larval stage is characterized by the presence of over 25 pairs of somites, the larvae are ready to swim, and they also present optical vesicle and lens, well defined miogenesis processes, and posterior intestine (Ninhaus-Silveira et al. 2006). Thus, phases 2 and 3 of the development of $P$. vivipara are related to the stages of segmentation and organogenesis, while phase 4 is related to the larval stage. However, free swimming only starts when the individual reaches phase 7 (fingerling) or post-natal stage.

We detected changes in the behavior of guppy fingerlings' MCs, as well as cell responses related to differential production of mucus that covered the epithelium surface. This is probably connected with the adaptive success of this species when exposed to different salinities, characterizing it as euryhalin. We suggest that the genetic factors and the sequenced cell activities internal to the animal are able to guarantee the events concerning development. Further, the external factors (biotic or abiotic), natural or promoted by anthropogenic activities, such as all kinds of pollution, temperature, salinity, and food availability, seem to be essential to provoke behavior changes in different types of cells.

The data herein presented demonstrate that there were no substantial behavior changes of specimens during exposure to different levels of salinity, such as loss of sense, direction, capacity to move and escape, and changes in rotational movements of the body. In the present study we observed that, in different stages of the post-natal period, the guppies manage to adapt to salinity ranging from 0 to $20 \%$, as described by Rосна et al. (2004). This characteristic is exclusive to just a few fish species because part of the metabolic energy is used in osmoregulation and modulation of morphophysiological characteristics of branchial epithelium cells. Such characteristic may be related to the maturity and differentiation of various types of MCs in addition to the changes in the content of their secretory granules. As MCs other than type IV appear, this modulation of cell behavior takes place only when the fish are exposed to variations in salinity level for a period of two hours.

The environmental conditions to which the fingerlings were exposed during this experiment, FW and BW $(5,10,15$, and 20\%o), induced changes in the content of glycoconjugates secreted by MCs, which corroborates the results reported by SABÓIA-Moraes et al. (1996) for adult guppies.

According to McManus (1948), Mowry (1956), SPIcER \& LilLie (1959), Lev \& Spicer (1964), Spicer et al. (1967), and Lillie \& Fullmer (1976), traditional histochemical analyses for the detection of the classical mucopolysacharides, currently named glycoconjugates, allow the detection of granular content in the cell cytoplasm, as well as the identification of free and/or associated sugars, which are also present on the surface that covers cells and/or tissues. Our results permit the arrangement of the glycoconjugates present in MCs of the guppy gills into three 
groups, acid carboxylated, acid sulphated, and containing 1,2vic-glycol groups. Animals exposed to FW 10\%o, presented MCs types III and IV much more reactive to PAS and high-viscosity mucus. These cells were reactive to $\mathrm{AB}$ pH 2.5 in all treatments in which they were detected. The histocytological analyses showed that MCs change the content of glycoprotein granules when the branchial epithelium is in contact with irritating agents, such as salt. The mucus synthesized by MCs is classified as mucin and forms a gel that is highly hydrophylic. Thus, after its secretion, the mucus would increase in volume due to rapid hydration. Góes \& TABOga (2005) reported that mucins are a group of highly heterogeneous macromolecules because of post-traductional processes, especially glycosilation. The hydrophylic nature of mucus accounts for its high viscosity, provides a physical barrier against irritating agents, avoids the penetration of microorganisms, and promotes the anchorage of proteins that possess protective function, a role played by the mucins released by distinct populations of MCs in the guppy branchial epithelium.

In the case of fingerlings, we only detected the presence of MCs type III, reactive to PAS and $\mathrm{AB}$ pH 2.5, in the branchial filaments region of the individuals exposed to different saline concentrations. The most reactive cells were present in animals exposed to FW for two hours. These animals were born in BW 20\%o and were transferred to FW 0\%. In all the cases analyzed, regardless of salinity, the only MC found was type IV, identified in the branchial ray region.

When they are born, guppies need their branchial epithelium cells to be functionally active (for instance, to be able to transport ions and secrete glycoconjugates) so that they can colonize environments that present variable levels of salinity. The presence of mitochondria-rich cells and MCs type III in fingerlings exposed to salinity changes, indicates that this species is able to respond to salt stress. From phase 3 on, we detected MCs distributed in the pharynx epithelium and in different parts of the digestive system after treatment with $\mathrm{AB} p \mathrm{H}$ 2.5. We observed MCs type IV in the branchial rays only from phase 3 on, when the four branchial arcs are formed. MCs in the branchial filament are only detected immediately after birth and after exposure to salinity changes.

When fingerlings are subjected to salinity variations, changes in the behavior of the branchial epithelium cells take place and other types of MCs appear in addition to type IV. This modulation of cell behavior was observed in animals born in both estuarine and continental environments. Increased production of fluid mucus is a feature that is likely to be related to lack of salinity (group exposed to FW 0\%o), since fingerlings not exposed to salt-rich environments do not need to produce a denser barrier to protect the branchial epithelium.

This modulation of branchial epithelium cell behavior in response to changes in the environment qualifies $P$. vivipara as a biological model to be used in studies to assess the activity of different compounds such as salt, fluorine, plant extracts from the Brazilian Cerrado region, as well as to diagnose envi- ronmental pollution caused by heavy metals, such as mercury and lead (Araújo et al. 2001, Breseghelo et al. 2004, Motter et al. 2004). Furthermore, guppies are also qualified as an important system-model for neotropical fish developmental biology research due to their small size and ease in handling, high reproductive effectiveness, high birth rates, and high number of fingerlings and embryos per female. All these features favor sampling, processing, maintenance, and handling in the laboratories, as well as the visualization of macro and microscopic characteristics, such as the gills.

Despite the favorable characteristics mentioned above, the guppies in our study presented filial cannibalism, defined as the consumption of one's own viable offspring (MANICA 2002). Such behavior may be in part a response to the stress caused by salinity or even due to intra-specific competition in order to find food.

The analyses of the morphological and histochemical characters of $P$. vivipara embryos, larvae, and fingerlings will contribute to a better understanding of the reproductive and developmental biology as well as the ecology of fish with internal fertilization, and also their importance to analyze historical evolution and phylogeny of the genus Poecilia.

\section{ACKNOWLEDGMENTS}

The authors are grateful to FAPESP, FUNAPE, and CNPq (PIBIC - UFG) for the financial and logistics support to the present research.

\section{LITERATURE CITED}

Araújo, E.J.A.; J.O.R. Morais; P.R. Souza \& S.M.T. Sabóia-Morais. 2001. Efeitos de poluentes químicos cumulativos e mutagênicos durante o desenvolvimento ontogenético de Poecilia vivipara (Cyprinodontiformes, Poeciliidae). Acta Scientiarum 23 (2): 391-399.

Bloch, M.E. \& J.G. Schneider. 1801. M. E. Blochii, Systema Ichthyologiae iconibus cx illustratum. Post obitum auctoris opus inchoatum absolvit, correxit, interpolavit Jo. Gottlob Schneider, Saxo. Berolini. Sumtibus Auctoris Impressum et Bibliopolio Sanderiano Commissum. Systema Ichthyology I$\mathrm{LX}+584 \mathrm{p}$.

BorÇATO, F.L.; N. Bazzoli \& Y SATO. 2004. Embriogenesis and larval ontogeny of the "piau-gordura", Leporinus piau (Fowler) (Pisces, Anostomidae) after induced spawning. Revista Brasileira de Zoologia 21 (1): 117-122.

Brasil. 2008. Lei $\mathrm{n}^{\circ} 11.794$, de 8 de outubro de 2008. Regulamenta o inciso VII do § 1 o do art. 225 da Constituição Federal, estabelecendo procedimentos para o uso científico de animais; revoga a Lei no 6.638, de 8 de maio de 1979; e dá outras providências. Diário Oficial da União, Brasília-DF, 9 out. 2008. Available online at http://www.planalto.gov.br/ ccivil/_Ato2007-2010/2008/Lei/L11794.htm [Accessed: 29/ I/2009]. 
Breseghelo, L.; M.P. Cardoso; R. Borges-de-Oliveira; M.F. Costa; J.C.B. Barreto; S.M.T Sabóia-Morais \& A.T. Yamada. 2004. Efeitos do fluoreto de sódio no epitélio da brânquia do peixe Guaru (Poecilia vivipara). Brazilian Journal of Veterinary Research and Animal Science 41 (4): 274-280.

Falk-Petersen, I.B. 2005. Comparative organ differentiation during early life stages of marine fish. Fish and Shellfish Immunology 19 (5): 397-412.

Gomes, B.V.C.; R.S. Scarpelli; F.P. Arantes; Y. Sato; N. Bazzoli \& E. Rizzo. 2007. Comparative oocyte morphology and early development in three species of trahiras from the São Francisco River basin, Brazil. Journal of Fish Biology 70 (5): 1412-1429.

Góes, R.M. \& S.R. Taboga. 2005. Células caliciformes, p. 163173. In: H.F. Carvalho \& C.B. Collares-Buzato (Orgs). Célula: uma abordagem multidisciplinar. Barueri, Manole, vol. $1,465 \mathrm{p}$.

KARNovSKY, M.J. 1965. A formaldehyde-glutaraldehyde fixative of high osmolality for use in electron microscopy. Journal of Cell Biology 27: 137-138.

Laurent, P.; H. Hobe \& S. Dunel-Erb. 1985. The role of environmental sodium chloride relative to calcium in gill morphology of freshwater salmonid fish. Cell and Tissue Research 240: 675-692.

Lev, R. \& S.S. SPICER. 1964. Specific staining of sulphate groups with alcian blue at low $\mathrm{pH}$. Journal of Histochemistry and Cytochemistry 12: 309.

Lillie, R. D. \& H.M. Fullmer. 1976. Chemical end groups, p. 217-326. In: R.D. LILLIE \& H.M. FulMER (Eds). Histopathologic technique and practical histochemistry. New York, McGraw-Hill, 946p.

Machado, M.R. \& E. Fanta. 2003. Effects of the organophosphorous methyl parathion on the branchial epithelium of a freshwater fish Metynnis roosevelti. Brazilian Archives of Biology and Technology 46 (3): 361-372.

McManus, J.F.A. 1948. Histological and histochemical uses of periodic acid. Stain Technology 23 (3): 99-108.

Manica, A. 2002. Filial cannibalism in teleost fish. Biological Reviews 77 (2): 261-277.

Motter, M.D.S.; L.D. Silva; R. Borges-De-Oliveira; A.T. Yamada; S.C. Santos \& S.M.T. Sabóia-Morais. 2004. Índice mitótico em células epiteliais da brânquia de Guaru (Poecilia vivipara) tratados com frações da casca do caule e da folha de pequi (Caryocar brasiliensis). Brazilian Journal of Veterinary Research and Animal Science 41 (4): 221-227.

Mowry, R.W. 1956. Alcian blue techniques for the histochemical study of acidic carbohydrates. Journal of Histochemistry and Cytochemistry 4: 407-408.

Moyle P.B. \& J.J. CeCh JR. 1996. Fishes: an introduction to ichthyology. $3^{\text {rd }}$ ed. New Jersey: Chapman \& Hall, 579p.

Nakatani, K.; A.A. Agostinho; G. Baumgartner; A. Bialtzki; P.V. Sanches; M.C. Makrakis \& C.S. Pavanelli. 2001. Ovos e peixes de água doce: desenvolvimento e manual de identificação. Maringá, EDUEM, 378p.

Ninhaus-Silveira, A.; F. Foresti \& A. Azevedo. 2006. Structural and ultrastructural analysis of embryonic development of Prochilodus lineatus (Valenciennes, 1836) (Characiforme; Prochilodontidae). Zygote 14 (3): 217-229.

Paffaro Jr, V.A.; M.C. Bizinotto; P.P. Joazeiro \& A.T. Yamada. 2003. Subset classification of mouse uterine natural killer cells by DBA lectin reactivity. Placenta 24 (5): 479-488.

Rocha, A.J.S.; V. Gomes; P.V. Ngan; M.J.A.C.R. Passos \& R.R. FúRIA. 2004. Metabolic demand and growth of juveniles of Centropomus parallelus as function of salinity. Journal of Experimental Marine Biology and Ecology 316 (2): 157165.

SABÓIA, S.M.T. \& P.H.M. FerRi. 1987. Detecção de mucopolissacarídeos (glicosaminaglicanas) nas células mucosas das brânquias de Poecilia vivipara (Pisces - Poeciliidae). Anais da Sociedade Nordestina de Zoologia 2 (2): 263-269.

Sabóia-Moraes, S. M. T.; F.J. Hernandez-Blazquez; D.L. Mota \& A.M. BitTencourt. 1996. Mucous cell types in the branchial epithelium of the euryhaline fish Poecilia vivipara. Journal of Fish Biology 49 (3): 545-548.

Sato, Y.; N. Fenerich-Verani; A.P.O. Nuner; H.P. Godinho \& J.R. Verani. 2003. Padrões reprodutivos de peixes da bacia do São Francisco, p. 229-274. In: H.P. GodinHo \& A.L. GodinHo (Eds). Águas, peixes e pescadores do São Francisco das Minas Gerais. Belo Horizonte, PUC Minas, 468p.

SpICER, S.S. \& R.D. LILLIE. 1959. Saponification as a means of selectively reversing the methylation blockade of tissue basophilia. Journal of Histochemistry and Cytochemistry 7: 123-125.

Sticer, S.S.; R.G. Horn \& T.J. Leppi. 1967. Histochemistry of connective tissue mucopolysaccharides. p. 251-303. In: B.M. Wagner \& D.E. Smith (Eds). The connective tissue. Baltimore, Williams \& Wilkins, 251-303p.

Vigliano, F.A.; N. Aleman; M.I. Quiroga \& J.M. Nieto. 2006. Ultrastructural characterization of gills in juveniles of the Argentinian silverside, Odontesthes bonariensis (Valenciennes, 1835) (Teleostei: Atheriniformes). Anatomia, Histologia e Embryologia 35 (2): 76-83.

Submitted: 11.V.2009; Accepted: 29.V.2010.

Editorial responsibility: Lucélia Donatti and

Carolina A. de Oliveira Freire 